\title{
Prevalence of work related neck and shoulder pain among office receptionist of Karachi
}

\section{Karaçi ofis resepsiyonistlerinde işle ilgili boyun ve omuz ağrısı prevalansı}

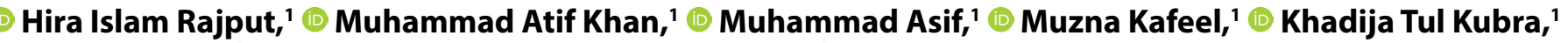 \\ (1) Muhammad Jawwad Baig Chughtai,' 이 Muhammad Riaz Baig Chughtai
}

\author{
'Isra Institute of Rehabilitation Sciences, Isra University, Karachi Campus, Pakistan \\ ${ }^{2}$ College of Physiotherapy, Jinnah Postgraduate Medical Centre, Karachi, Pakistan
}

\begin{abstract}
Introduction: To determine the prevalence of work related neck and shoulder pain among office receptionist of Karachi.

Methods: It was a cross sectional study. Office receptionists from different private organizations of Karachi were selected by convenient sampling. After approval from Institutional Ethical Review Committee of Isra University, data was collected from January 2018 to June 2018. We selected office receptionist from both gender between 22 to 41 years of age. Those participants who had work experience of about one year using computer for at least two hours. A self-administered questionnaire was used to determine the work related neck and shoulder pain. Data was analyzed by SPSS version 21. Results: The highest prevalence of work related neck and shoulder pain was found and their frequency was 72 and $62.61 \%$ participants responded that pain starts when they perform their work. $47 \%$ participants responded that they keep their neck in bending position and shoulders elevated while using computer.

Discussion and Conclusion: The prevalence of work related neck pain and shoulder pain among office receptionist was $72 \%$. Symptoms increases with the increase contact time with the computer. So the complaints of work related neck and shoulder pain among receptionist of Karachi are much higher when they perform their work. Therefore, it is recommended that as postural training and ergonomically designed furniture can decrease complaints of pain and occurrence of injuries, increase productivity, improve morale, and decrease work-related musculoskeletal disorders.
\end{abstract}

Keywords: Computer user; neck pain; postural training; prevalence; shoulder pain; work related musculoskeletal disorders

$\mathrm{M}$ usculoskeletal Disorders due to work (WMSD) [also known as Repetitive Strain Injury (RSI) or Cumulative
Özet

Amaç: Karaçi ofis resepsiyonistlerinde işle ilgili boyun ve omuz ağrısı prevalansını belirlemek.

Gereç ve Yöntem: Kesitsel bir çalışmadır. Karaçi'nin farklı özel kuruluşlarından ofis resepsiyonistleri uygun örnekleme ile seçildi. İsra Üniversitesi Etik İnceleme Komitesi'nden onay alındıktan sonra, veriler Ocak 2018 ile Haziran 2018 arasında toplandı. 22 ila 41 yaşları arasında her iki cinsiyetten en az iki saat boyunca bilgisayarı kullanan yaklaşık bir yıl iş tecrübesine sahip ofis resepsiyonistleri seçildi. Işe bağlı boyun ve omuz ağrısını belirlemek için kendi kendine uygulanan bir anket kullanılmışıı. Veriler SPSS 21 versiyonunda analiz edildi.

Bulgular: Işe bağlı en yüksek boyun ve omuz ağrısı prevalansının olduğu tespit edildi ve sıkı̆̆ı 72 ve 62 idi. Katılımcıların\% 61'i işlerini yaparken ağrı başladığını belirtti. Katılımcıların\% 47'si boyunlarını bükülme pozisyonunda tuttuklarını ve bilgisayar kullanırken omuzlarının yüksek olduğunu belirtti.

Sonuç: Ofis resepsiyonistlerinde işe bağlı boyun ağrısı ve omuz ağrısı prevalansı \%72 idi. Bilgisayarla temas süresinin artmasıyla birlikte belirtiler artar. Bu nedenle, Karaçi resepsiyonistleri arasında işle ilgili boyun ve omuz ağrısı şikayetleri iş̧lerini yaparken çok daha fazladır. Bu nedenle postural eğitim ve ergonomik tasarımlı mobilyaların ağrı şikayetlerini ve yaralanma olaylarını azaltabileceği, üretkenliği arttıracağı, morali iyileştirebileceği ve işe bağlı kas-iskelet sistemi rahatsızıklarını azaltabileceği önerilmektedir.

Anahtar Sözcükler: Bilgisayar kullanıcısı; boyun ağrısı; postural eğitim; prevalans; omuz ağııs; işe bağlı kas-iskelet hastalıkları.

Trauma Disorder (CTD)] are the musculoskeletal disorders that have been developed due to work related issues. It may

Corresponding (iletişim): Hira Islam Rajput, ST-7/A, Block-5, Gulshan-e-lqbal, Karachi, Sindh, Pakistan 
involve different regions of body like upper extremity, lower extremity, cervical, back regions etc. The onset of these problems need to be known where as it is a common belief that it is caused by overuse. ${ }^{[1]}$

Increased computer usage has been linked to a high prevalence of musculoskeletal symptoms in the neck and upper extremities. ${ }^{[2]}$ Office workers are frequently exposed to repetitive movement, awkward postures and manual handling tasks which are risk factors for developing musculoskeletal symptoms. ${ }^{[3]}$ They may also encounter psychosocial problems such as time pressures and stressful work. The role of psychosocial factors in the development and persistence of musculoskeletal symptoms is well recognized. ${ }^{[2,3]}$

Pain, discomfort and disability in the neck, upper and lower limbs, and back are prevalent amongst people who are working. The conditions are most commonly known as musculoskeletal disorders (MSDs). ${ }^{[4]}$ MSD is impairments of joints, ligaments, muscles and its tendons, and the nerves or blood vessels supplied; with poor or localized circulation of blood, are caused by, depending on the work performance, and also by immediate environmental factors in which work is completed. Many of the musculoskeletal disorders are work related disorder and are multiplying disorders; which are due to repetitive risk factor to low or high intensity loads for a prolong period of time. Though, acute traumas like fractures; resulting from an accident, can also cause musculoskeletal disorders. MSD symptoms can differ from pain and discomfort to disability and reduced functions of the body. ${ }^{[4-6]}$

The skeletal makeup weaknesses are also a causing factor initiating occupational injuries, also working under normal stress conditions. Along with physical, biomechanical and ergonomics stressors, its causes also consist of psychosocial and risk relating to organization for example: stress relating occupation, poor community support, repetitive actions, depression and anxiety, between others. ${ }^{[7]}$

Neck and shoulder pain have been defined as ache, discomfort, stiffness, spasm, numbness, tenderness, and muscle pain in several studies. Symptoms like pain, stiffness, aches etc are difficult to separate from each other in relation to their origin. Although most studies consider the neck and shoulder pain as a separate region while few studies consider the neck and shoulder pain combine. ${ }^{[8]}$

The structural and functional components of the human spine are divided into two categories that are hard and soft tissues. Hard tissue consist of vertebrae and intervertebral discs, function as load bearing and they are resilient to compressive forces which are continuously being applied to the spine in different activities. ${ }^{[9]}$

The soft tissue component includes muscles and ligaments, attached to the cervical spine. Muscles are responsible to perform different movement of the neck while ligaments stabilize the cervical spine in static posture as well as during movements.

Although there is very limited range of motion occurring at
Table 1. Demographic data of participants

\section{Demographic data}

Frequency

Age of the respondent $(n=100)$

22 to 26 years

18

27 to 31 years

45

32 to 36 years

23

37 to 41 years

Gender of the respondent $(n=100)$

Male

46

Female

Working years $(n=100)$

1-2 years

40

3-4 years

33

$>5$ years

27

each joint of the cervical spine. But combined motion of all segments makes the cervical spine as the most mobile part of the human vertebral column and about 140 degrees of sagittal plane, 180 degrees of transverse plane and about 90 degrees of frontal plane movements are taking place at the cervical spine. ${ }^{[10]}$

Pectoral girdle is also called as the shoulder girdle, consist of clavicle (collar bone), the flat triangular bone, the scapula and the longest bone of the upper limb, the humerus. The clavicle is the only bone which connects the appendicular skeleton with the axial skeleton and forms the sternoclavicular joint with sternum and acromioclavicular joint with the acromion process of the scapula. ${ }^{[11]}$

The shoulder joint is the most unstable and most dynamic joint in the human body because glenoid cavity is a shallow cavity which is deepened by the glenoid labrum that increases its stability. Apart from labrum and joint capsule, the stability of the shoulder joint is mostly depended on the muscles which are surrounding this joint. The muscles which surround the shoulder joint are called as rotator cuff muscles. ${ }^{[12,13]}$ There is direct relation between a good work place and its impact on the quality of the productivity of human. ${ }^{[12]}$ The physical aspects of a workplace environment can have a direct impact on the productivity, health and safety, comfort, concentration, job satisfaction and morale of the people within it. Important factors in the work environment that should be considered include building design and age, workplace layout, workstation set-up, furniture and equipment design and quality, space, temperature, ventilation, lighting, noise, vibration, radiation, air quality (work environment). ${ }^{[14]}$ Musculoskeletal pain is a known consequence of repetitive strain, overuse, and work related disorders. These injuries include a variety of disorders that cause pain in bones, joints, muscles or surrounding structures. The pain can be acute or chronic, focal or diffuse. ${ }^{[15]}$ MSDs are among the leading reasons of work related disabilities and being absent from work. ${ }^{[5,16]}$ This study finds out the prevalence of work related neck and shoulder pain among of- 


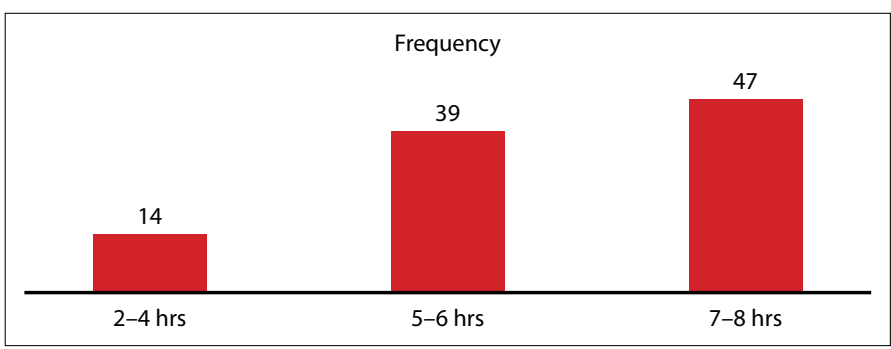

Figure 1. Frequency of participants who spent their time in front of computer.

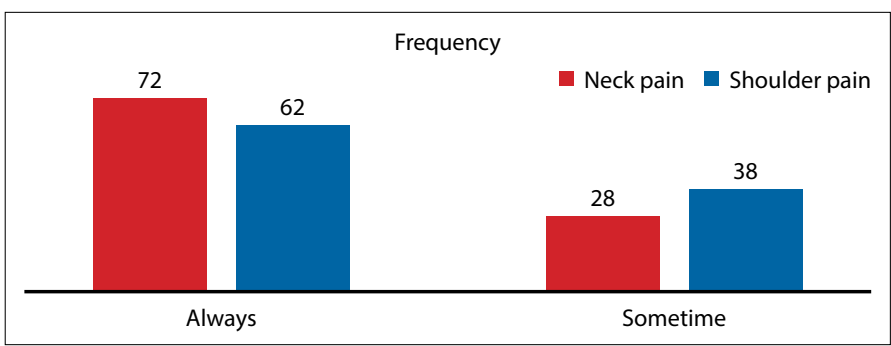

Figure 2. Participants who suffer from neck and shoulder pain.

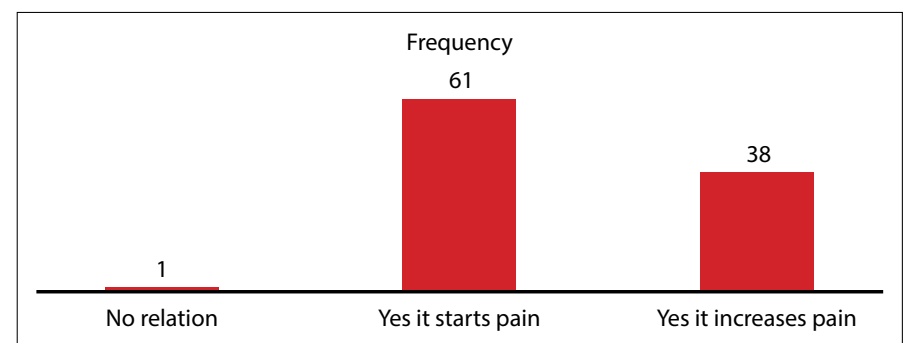

Figure 3. Frequency of work and pain among office receptionist.

fice receptionist in different organizations of Karachi. With the help of this research the level of awareness of postural training and ergonomically assessment may be enhanced among receptionist working in different organization of Karachi and by this study the receptionist would be able to work efficiently.

\section{Material and Methods}

It was a cross sectional study that was conducted in Isra Institute of Rehabilitation Sciences Karachi Campus. This study was approved from the institutional ethical review committee of Isra University vide number IERC/IIRS-IU-KC/17/07. The duration of the study was six months from January 2018 to June 2018. 100 participants were selected by convenient sampling from different private organizations (Bank, institutes, multinational companies) of Karachi and sample size was calculated by Roasoft sample size calculator. The targeted population of this study was both gender office receptionist aged between 22 to 41 years and had a work experience of about one year using computer for at least two hours were included in this study. Receptionist aged above 41 years and below 22 years were excluded from this study because degenerative changes mostly find in this age group. Those employees who had a history of severe trauma, such as a fracture, neurological injury involving the spine, shoulders or head, or a recent whiplash injury (i.e. less than two years ago) were also excluded from the study. After the signing of consent form, self-administered questionnaire was distributed to the participants. The first part of the questionnaire contained questions concerned participants' demographic details: age, gender, occupations, working hours per day in front of computer, place of work, duty, and work experience. The second part of the questionnaire was consisting of questions regarding frequency, severity, nature and duration of neck and shoulder pain and question regarding relationship of pain with work. The questionnaire was based on close ended questions. Gathered data was coded and analyzed by software Statistical Package for Social Sciences (version 21.0). Prevalence, Frequency and percentages were calculated.

\section{Results}

100 office receptionists were selected from different organizations of Karachi, in Table 1 shows the demographics details of the participants. In which the mean value of age (mean 30), and having a standard deviation of (S.D \pm 10.357 ). Ratios of female respondents were greater (54) as compared to males (46). Time duration has been described which was being spent by the respondent in front of computer. Those participants who were working from 1-2 years were 40 out of 100 participants, 33 participants were working from 3-4 years whereas 27 participants were working from more than 5 years. In Figure 1 shows Frequency of participants who spent their time in front of computer. Those participants who were spending about 7 to 8 hours in front of computer were 47 out of 100 participants and 39 participants who were spending about 5 to 6 hours in front of computer whereas 14 participants were spending about 4 to 4 hours in front of computer. Figure 2 shows the frequency of participants who suffer From Neck and Shoulder Pain, 72 participants had 'always' neck pain whereas 28 participants had 'sometime' neck pain. 62 participants had always shoulder pain whereas 38 had 'sometime' shoulder pain when using computer. Prevalence rate of work related neck and shoulder pain was $72 \%$. Figure 3 shows the relationship of pain and work, 61 participants answered they have relationship of work and pain, 38 participants answered their pain start and increased with the use of computer where as one participants had no relationship.

\section{Discussion}

Majority of the participants showed that they always suffered from neck and shoulder pain. It is the first research that finds out the prevalence of work related neck and shoulder pain among office receptionist working in different organization of Karachi. This study emphasize to determine the prevalence of upper extremity Work related Musculoskeletal disorders in intense computer users and the results showed that the relationship between work and development of neck and shoulder pain. The previous research showed a high prevalence of 
upper extremity cumulative disorders among long term desktop users and concluded that there was a positive relationship between neck and shoulder pain and work. ${ }^{[17]}$ These results similar with our study among office receptionist of the Karachi with prevalence of $72 \%$ of complaints of neck and shoulder pain. Furthermore, these results are inconsistent with the study that was conducted in the Sudan, which shows highest complaints of arm, neck and shoulder pain complaints for the duration of at least one week over a one-year. The result of our study is also not supporting the study which was conducted in the Netherlands shows high prevalence of neck, arm and shoulder pain among computer users for at least one week period of time. A survey was carried in the Netherlands during the years 2002 and 2004 concluded that low prevalence of neck, shoulder pain was found in 12 months period of time. ${ }^{[18]}$

Furthermore research shows that prevalence of work related musculoskeletal disorders is more common in all ages of females as compared to males. Most of the population showed a positive relation between their work and pain and they responded that either pain starts or exaggerate when they use computer. The previous research' results showed that although a large number of population keep their arms and forearms perpendicular to the ground but their elbows and shoulders are not closed to the body rather their shoulder remain abducted position this is usually because of the placement of the mouse or input device too far so the user had to keep his or her shoulder in abducted position. ${ }^{[18]}$

In this study they suggested that poor head and neck posture is the main cause of pain in the region of neck and shoulder among the office workers. This study assessed and compared posture of office workers with or without symptoms of having discomfort in the region of head, neck and shoulder. Symptomatic subjects also showed protracted acromion and greater movement in head region as compared to asymptomatic subject. It was demonstrated $10 \%$ increase in head posture in all subjects as compared with their relaxed position, and it was also noticed that everyone's posture remain same throughout the time period. ${ }^{[19]}$

This study determines a relationship between severity of incorrect posture and frequency of neck and shoulder pain. Future research is needed, however, to determine the postural training which improves the postural alignment can reduce the incidence of neck and shoulder pain. It is predictable to found what the associations are between pain reduction and postural training in order to give the reasons of management of postural correction and exercise techniques used in clinical practice. Future research in the area of quantifying postural abnormalities would also be beneficial in establishing what relationships do exist.

\section{Conclusion}

The prevalence of work related neck and shoulder pain among office receptionist was $72 \%$. So the complaints of neck and shoulder pain among office receptionist of Karachi are much higher when using computer. As ergonomically designed furniture and postural training programs can decrease the complaints of pain and occurrence of injuries, increase productivity, improve morale, and decrease work-related musculoskeletal disorders.

Acknowledgements: First of all I pay my thanks to almighty Allah for giving me strength and determination to complete this work. I have been extremely privileged to share experiences and knowledge with, and to be supported by, a great number of excellent people. For this piece of work I pay my deepest gratitude to my supervisors Dr. Syed Hyder Raza Naqvi, Dr. M. Athar Majeed Khan \& Dr. Muhammad Asif. Their vigilant supervision, encouragements, positive criticism and guidance always acted as a beacon house during my journey of learning and writing. I am deeply thankful to my friends and all my colleagues for constant help and advice during the difficult part of my work. I found myself short of words to express my thanks to my parents and my family members \& specially my son Muhammad Ibrahim Khan who always supported me throughout the study period. I am also thankful to all my seniors who helped me and given me their valuable suggestions in the completion of this project and the participants who voluntarily involved in this study and took part in this survey.

Conflict of interest: There are no relevant conflicts of interest to disclose.

\section{References}

1. Abaraogu UO, Olawale OA, Odebiyi D.O, Ezeukwu Oa, Ezema $\mathrm{Ci}$, "Self Reported Work Organization indices factors are associated with prevalence of work related musculoskeletal disorders among Bottling Workers. Across sectional study," Continental Journal Applied Science, 2012; 7(2): 28-34.

2. Sillanpa“a” J, Huikko S, Nyberg M, Kivi P, Laippala P, Uitti J. Effect of work with visual display units on musculo-skeletal disorders in the office environment. Occup Med (Lond) 2003;53:443-451.

3. Bernard BP. Musculoskeletal Disorders and Workplace Factors. Cincinnati, $\mathrm{OH}$ : US Department of Health and Human Services, National Institute of Occupational Safety and Health, 1997.

4. Punnett $\mathrm{L}$, Wegman $\mathrm{DH}$, Work-related musculoskeletal disorders: the epidemiologic evidence and the debate, J ElectromyogrKinesiol. 2004;14(1), pp:13-23.

5. Auerbach JD. Musculoskeletal disorders among spine surgeons: results of a survey of the Scoliosis Research Society membership, Spine, 2011;15(8),: 715-21.

6. Desai F, Tehrani Banihashemi A, J. The prevalence of COPCORD study (stage 1, rural study) in Iran. ClinRheumatol; 2012; 28(7): 248.

7. Evangelos $C$. Prevalence of musculoskeletal disorders in dentists,BMC Musculoskeletal Disorders, 2004; 5(6): 5-16.

8. Grace P. Y. Szeto. Work-related Musculoskeletal Symptoms in Surgeons, Journal of Occupational Rehabilitation, 2009; 19(7): 175184.

9. Walker-Bone K, Reading I, Coggon D, Cooper C, Palmer KT. 'The anatomical pattern and determinants of pain in the neck and upper limbs: an epidemiologic study' Pain. 2004: 109 (1-2): 45-51. 
10. Hunt IM, Silman AJ, Benjamin S, Mcbeth J, Macfarlane GJ. 'The prevalence and associated features of chronic widespread pain in the community using the 'Manchester' definition of chronic widespread Pain' Rheumatology (Oxford). 1999: 38 (3): 275-279.

11. Sluiter JK, Rest KM, Frings-Dresen MH. 'Criteria document for evaluating the work-relatedness of upper-extremity musculoskeletal disorders' Scand J Work Environ Health, 2001: 27 (1): 1-102.

12. Kuorinka I, Jonsson B, Kilbom A, Vinterberg $H$, Biering-Sorensen $F$, Andersson G, Jorgensen K. 'Standardised Nordic questionnaires for the analysis of musculoskeletal symptoms' Appl Ergon. 1987: 18 (3): 233-237.

13. Halberg, M. 'In Encyclopedia of Occupational Health and Safety' Stellman, J.M, Editor. International Labor Office: Geneva. 1998:618.

14. Palmer, K.T. Smedley J. 'Work relatedness of chronic neck pain with physical findings-a systematic review' Scand J Work Environ Health. 2007: 33 (3): 165-191.
15. Dvorak J, Antinnes JA, Panjabi M, Loustalot D, Bonomo M. 'Age and gender related normal motion of the cervical spine' Spine. 1992: 17 (10): 393-298.

16. Donatelli, R.A.'Physical Therapy of the Shoulder 2004: 4th Edition. U.S.A.: Churchil Livingstone.

17. Aydeniz, A. Gursoy, S. 'Upper Extremity Musculoskeletal Disorders among Computer Users' Turk Journal of Medical Sciences. 2008: 38 (3): 235-238.

18. Eltayeb SM, Staal JB, Hassan AA, Awad SS, De Bie RA. 'Complaints of the arm, neck and shoulder among computer office workers in Sudan: a prevalence study with validation of an Arabic risk factors questionnaire' Environmental Health, 2008: 7 (33): 1186-1476.

19. Griegel-Morris P, Larson K, Mueller-Klaus K, Oatis CA. 'Incidence of Common Postural Abnormalities in the Cervical, Shoulder and Thoracic Regions and Their Association with Pain in Two Age Groups of Healthy Subjects' Physical Therapy. 1992: 72 (6): 425430. 